\title{
Molecular identification and further characterization of Arcanobacterium pyogenes isolated from bovine mastitis and from various other origins
}

\author{
M. Hijazin, ${ }^{*}$ H. Ülbegi-Mohyla, ${ }^{\star}$ J. Alber, ${ }^{\star}$ C. Lämmler, ${ }^{\star 1}$ A. A. Hassan, † A. Abdulmawjood,‡ \\ E. Prenger-Berninghoff,§ R. Weiß,§ and M. Zschöck\| \\ *Institut für Pharmakologie und Toxikologie, Justus-Liebig-Universität Gießen, Frankfurter Str. 107, 35392 Gießen, Germany \\ †GD Animal Health Service, Department of Bacteriology and Parasitology, Postbus 9, 7400 AA Deventer, the Netherlands \\ łInstitut für Tierärztliche Nahrungsmittelkunde, Justus-Liebig-Universität Gießen, Frankfurter Str. 92, 35392 Gießen, Germany \\ §Institut für Hygiene und Infektionskrankheiten der Tiere, Justus-Liebig-Universität Gießen, Frankfurter Str. 85-91, 35392 Gießen, Germany \\ ||Landesbetrieb Hessisches Landeslabor, Schubertstr. 60, 35392 Gießen, Germany
}

\begin{abstract}
The present study was designed to identify phenotypically and genotypically 61 Arcanobacterium pyogenes isolated from bovine mastitis and from various other origins. The A. pyogenes isolates showed the typical cultural and biochemical properties of this species and displayed CAMP-like synergistic hemolytic activities with various indicator strains. The species identity could be confirmed genotypically by amplification and sequencing of the superoxide dismutase A encoding gene $\operatorname{sod} A$ of reference strains representing 8 species of genus Arcanobacterium and subsequent design of $A$. pyogenes sodA gene-specific oligonucleotide primer. The $A$. pyogenes sodA gene-specific oligonucleotide primer allowed, together with previously described $A$. pyogenes 16S-23S rDNA intergenic spacer region-specific oligonucleotide primer, a reliable molecular identification of all $61 \mathrm{~A}$. pyogenes of various origins. The additionally performed PCR-mediated amplification of 5 known and putative virulence factor encoding genes revealed that $100,20,87,75$, and $98 \%$ of the A. pyogenes carried the genes plo, cbpA, nanH, nanP, and fimA, which allowed an individual strain characterization. This might help to elucidate the role the putative virulence factors play in bovine mastitis and in various other infections caused by this bacterial pathogen.
\end{abstract}

Key words: Arcanobacterium pyogenes, mastitis, molecular identification, virulence gene

\section{INTRODUCTION}

Arcanobacterium pyogenes is a worldwide known pathogen of domestic ruminants and pigs causing mastitis, abortion, and a variety of pyogenic infections

\footnotetext{
Received August 3, 2010.

Accepted December 20, 2010.

${ }^{1}$ Corresponding author: Christoph.Laemmler@vetmed.uni-giessen.
} de
(Lämmler and Hartwigk, 1995; Moore et al., 2010). As summarized by Jost and Billington (2005), this bacterial pathogen is also able to cause disease in a large number of animal species, including antelopes, bison, camels, chicken, deer, elephants, gazelles, horses, macaws, reindeer, turkeys, and wildebeest, and also in companion animals such as dogs and cats. The A. pyogenes from companion animals were isolated from feline otitis externa and canine cystitis (Billington et al., 2002). A septicemia case of a farmer in Brazil caused by $A$. pyogenes had been described previously (Levy et al. 2009). A first case of endocarditis in a man with no identified animal contact was described by Plamondon et al. (2007). These authors also summarized 13 human cases of A. pyogenes infections.

According to a proposal of Yassin et al., (2010) A. pyogenes, Arcanobacterium abortisuis, Arcanobacterium bernardiae, Arcanobacterium bialowiezense, and Arcanobacterium bonasi should be reclassified in the newly described genus Trueperella. The genus Arcanobacterium should be restricted to Arcanobacterium hemolyticum, Arcanobacterium hippocoleae, Arcanobacterium phocae, and Arcanobacterium pluranimalium.

Arcanobacterium pyogenes possesses several known and putative virulence factors that may contribute to its pathogenic potential. These virulence factors include a hemolysin which is known as pyolysin and promotes hemolytic activities for red blood cells and cytolytic activities for immune cells (Jost and Billington, 2005); 2 neuraminidases ( $\mathrm{NanH}$ and $\mathrm{NanP}$ ), necessary for adhesion to epithelial cells (Jost et al., 2001, 2002); a collagen-binding protein ( $\mathrm{CbpA})$, necessary for adhesion to collagen rich tissues (Esmay et al. 2003); and fimbriae, which also might be involved in the adhesion process (Jost and Billington, 2005).

The identification of $A$. pyogenes is usually performed by cultural and biochemical properties. As shown previously, a PCR-mediated identification of 2 isolates of this bacterial species isolated from a gecko and a bearded dragon could be conducted by using $16 \mathrm{~S}$ rDNA, the 
Table 1. Origin of the 61 Arcanobacterium pyogenes isolates investigated in the present study

\begin{tabular}{|c|c|c|}
\hline Animal species & $\mathrm{n}$ & Origin/clinical diagnosis and additional information ${ }^{1}$ \\
\hline Bovine & 14 & $\begin{array}{l}\text { Uterus/endometritis and fertility problems (3); placenta/septicemia (1); cervix/vaginal discharge } \\
\text { and fertility problems (1); lung/bronchopneumonia and pleuropneumonia (2); lung/septicemia (1); } \\
\text { kidney/septicemia (1); urine/pyelonephritis (1); feces/septicemia (1); dermoid cyst/abscessation } \\
\text { (1); nostril abscess/bronchopneumonia and respiratory disorders (1); inguinal region/n.d. (1) }\end{array}$ \\
\hline Pig & 13 & $\begin{array}{l}\text { Lung/bronchopneumonia and pleuropneumonia (4), lung/septicemia (1), lung/n.d. (1); liver/ } \\
\text { septicemia (2); cervix/abortion, vaginal discharge, and fertility problems (2); ventricle/ } \\
\text { opisthotonus (1); ear abscess/perichondritis of ear cartilage (1); hind leg/abscessation (1) }\end{array}$ \\
\hline Sheep & 4 & Kidney/septicemia (1); skin/n.d. (2); n.d. (1) \\
\hline Goat & 1 & Lung/septicemia \\
\hline \multicolumn{3}{|l|}{ Wild ruminants } \\
\hline Elk & 1 & Rumen/septicemia \\
\hline Yak & 1 & Lung/thorax edema \\
\hline Deer & 2 & Lung/pneumonia (1); brain/septicemia (1) \\
\hline Mountain Reedbuck & 1 & Tonsils/n.d. \\
\hline Rat & 1 & Liver/septicemia \\
\hline \multicolumn{3}{|l|}{ Reptiles } \\
\hline Bearded dragon & 1 & Lung/septicemia \\
\hline Gecko & 1 & Intestine/enteritis, septicemia \\
\hline
\end{tabular}

${ }^{1}$ Numbers of isolates are in parentheses. n.d. $=$ no data available.

16S-23S rDNA intergenic spacer region (ISR), the pyolysin encoding gene plo, and the $\beta$ subunit of RNA polymerase encoding gene $r p o \mathrm{~B}$ as molecular targets (Ülbegi-Mohyla et al., 2010b).

The objective of the present study was to investigate the usefulness of the previously investigated molecular targets ISR and plo and, comparatively to the molecular identification of bacteria of genus Mycobacterium (Zolg and Philippi-Schulz, 1994), the superoxide dismutase A encoding gene sodA for molecular identification of $A$. pyogenes isolated from bovine mastitis and from several other origins. The $A$. pyogenes isolates were also investigated for the potential virulence factor encoding genes $\operatorname{cbp} A, n a n H, n a n P$, and $\operatorname{fim} A$.

\section{MATERIALS AND METHODS}

A total of 71 bacterial cultures were investigated in the present study. The cultures included 10 reference strains of 9 species of genus Arcanobacterium (Hassan et al., 2009; Ülbegi-Mohyla et al., 2010a,b). The other $61 \mathrm{~A}$. pyogenes isolates were obtained from bovine mastitis $(\mathrm{n}=15)$, nonmastitic origin of bovines $(\mathrm{n}=14)$, from pigs $(\mathrm{n}=13)$, small ruminants $(\mathrm{n}=5)$, wild ruminants $(\mathrm{n}=5)$, from a horse $(\mathrm{n}=1)$, from companion animals $(\mathrm{n}=4)$, from a rabbit $(\mathrm{n}=1)$, a rat $(\mathrm{n}=1)$, and from reptiles $(\mathrm{n}=2)$. The $A$. pyogenes of reptile origin has been described previously (Ülbegi-Mohyla et al., 2010b). The origin of the isolates is summarized in Table 1.

The A. pyogenes isolates were investigated for cultural and biochemical properties and for CAMP-like synergistic hemolytic activities as described by Hassan et al. (2009) and Ülbegi-Mohyla et al. (2009). For molecular identification, the superoxide dismutase A encoding gene sodA of $A$. bernardiae DSM $9152^{\mathrm{T}}$, A. hemolyticum DSM $20595^{\mathrm{T}}$, A. phocae DSM $10002^{\mathrm{T}}$, A. pluranimalium DSM $13483^{\mathrm{T}}$, and A. pyogenes DSM $20630^{\mathrm{T}}$ was amplified with the universal oligonucleotide primer pair described by Zolg and Philippi-Schulz (1994), and of A. abortisuis DSM $19515^{\mathrm{T}}$, A. bonasi DSM $17163^{\mathrm{T}}$, and A. hippocoleae DSM $15539^{\mathrm{T}}$ by designing a novel oligonucleotide primer pair using the $\operatorname{sodA}$ sequences obtained in the present study. The DNA extraction, sequencing, and alignment studies were performed as described previously (Hassan et al., 2008, 2009). The amplified sodA genes were compared by dendrogram analysis. The sodA gene sequence of $A$. pyogenes additionally allowed the design of a species-specific oligonucleotide primer pair with the help of OLIGO 4 primer analysis software (version 4.0). The $A$. pyogenes isolates were also investigated using the $A$. pyogenes ISR specific oligonucleotide primers described previously (Ülbegi-Mohyla et al., 2010b). The oligonucleotide primers used in this study were synthesized by MWG Biotech/Operon (Ebersberg, Germany). 
In addition, all $A$. pyogenes were investigated by amplification of pyolysin-encoding gene plo, collagenbinding protein-encoding gene $\operatorname{cbp} A$, neuraminidase ( $\mathrm{NanH}$ and $\mathrm{NanP}$ )-encoding genes nanH and nanP, and the fimbriae-encoding gene fim $A$. The oligonucleotide primer sequences, the thermal cycler PCR programs, and the expected amplicon sizes are summarized in Table 2.

The statistical analysis of the distribution of the putative virulence genes was performed with the statistical program package BMDP (Dixon, 1993); the comparison of the gene distribution between $A$. pyogenes of different animal origins was done by 4 -fold table followed by the 2-sided Fisher exact test.

\section{RESULTS AND DISCUSSION}

All 61 bacterial isolates investigated in the present study could be identified phenotypically and genotypically as $A$. pyogenes. Comparable to the $A$. pyogenes reference strains and to previous findings (ÜlbegiMohyla et al., 2009), all A. pyogenes isolates displayed a synergistic CAMP-like hemolysis with staphylococcal $\beta$-hemolysin and Rhodococcus equi, A. hemolyticum, and $A$. phocae indicator strains, a liquefaction of Loeffler agar, and a cross-reaction with streptococcal serogroup G-specific antisera. The latter are well-known properties of A. pyogenes (Bisping and Amtsberg, 1988; Lämmler and Hartwigk, 1995). In addition, all A. pyogenes showed the typical biochemical properties of this species (data not shown), which generally corresponded to the findings of Ding and Lämmler (1992) and Ramos et al. (1997).

With the available universal sodA gene-specific oligonucleotide primers, the sodA gene of A. pyogenes and of 7 additional species of genus Arcanobacterium (excluding $A$. bialowiezense) could be amplified and sequenced. Comparable to the previously described ISR, 23S rRNA and rpoB sequence data (Hassan et al., 2008; Ülbegi-Mohyla et al., 2010a,b), gene sodA appeared to be a novel target for molecular identification of bacteria of genus Arcanobacterium. The sodA gene sequence data of 8 species of genus Arcanobacterium were given to GenBank (FN562416, AM989465, FM955147, AM983534, FM242696, AM946391, AM989466, and AM949566). A dendrogram analysis of gene $\operatorname{sodA}$ of 8 species of genus Arcanobacterium is shown in Figure 1. Sequencing sodA additionally allowed the design of A. pyogenes-specific oligonucleotide primers. The $A$. pyogenes sodA gene-specific oligonucleotide primer and the previously described $A$. pyogenes ISR-specific oligonucleotide primer (Ülbegi-Mohyla et al., 2010b) could be used for PCR-mediated identification of all $61 A$. pyogenes investigated in the present study and both $A$. pyogenes reference strains. A typical amplicon of the $A$. pyogenes sodA gene-specific PCR is shown in Figure 2 . The $A$. pyogenes sodA gene-specific oligonucleotide primer showed no cross-reactions with reference strains representing the remaining 8 species of genus Arcanobacterium, indicating that both A. pyogenesspecific oligonucleotide primer pairs could successfully be used for molecular identification of this species.

Amplification of the known and putative virulence factor-encoding genes revealed that 100, 20, 87, 75, and $98 \%$ of the A. pyogenes isolates carried the genes plo, $\operatorname{cbp} A$, nanH, nanP, and fimA, respectively. Gene plo expresses the cholesterol-dependent pyolysin, which is well known as a major virulence factor of this species (Ding and Lämmler, 1996; Billington et al., 1997; Jost and Billington, 2005) and, because it is generally present in all A. pyogenes isolates, could be used for molecular identification of this species (Billington et al., 2002; Ertaş et al., 2005; Ülbegi-Mohyla et al., 2010b).

Jost and Billington (2005) additionally described a collagen-binding protein $\mathrm{CbpA}$, which seems to promote the adhesion of these bacteria to collagen-rich tissues. According to the findings of Pietrocola et al. (2007), CbpA also binds to fibronectin. However, collagen and fibronectin bind on different subsites of CbpA. As shown in the present study, the putative virulence factor CbpA-encoding gene $\operatorname{cbp} A$ seems to be present in $A$. pyogenes isolated from pigs (54\%), companion animals (25\%), and reptiles (100\%), but rarely in A. pyogenes from bovine origin (7\%). Arcanobacterium pyogenes from small and wild ruminants and from horse, rabbit, and rat did not carry gene $\operatorname{cbp} A$. As shown in Table 3, the differences in the presence of $c b p A$ between isolates from ruminants and pigs appeared to be significant $(P$ $=0.0004)$. According to the DNA dot blotting results of Esmay et al. (2003), cbpA was found in A. pyogenes of bovine (49\%), porcine (40\%), and avian (100\%) origin. Isolates from canines and from feline origin did not carry $c b p A$. Silva et al. (2008) could detect $c b p A$ in all 57 investigated $A$. pyogenes isolated from cows with uterine infections. The results of the present study corresponded to the findings of Santos et al. (2010) who found $\operatorname{cbp} A$ only in $1.4 \%$ of the A. pyogenes isolated from bovine origin. However, in contrast to Silva et al. (2008) and Santos et al. (2010), in the present study, $c b p A$ could also be found for reference strain $A$. pyogenes DSM $20630^{\mathrm{T}}$ (ATCC 19411), originally isolated from a pig. These differences could possibly be explained by the differing oligonucleotide primer pairs used for amplification of this potential virulence gene. Using the $\operatorname{cbp} A$-specific oligonucleotide primer proposed by Silva et al. (2008), A. pyogenes DSM $20630^{\mathrm{T}}$ was negative (data not shown). However, using the $c b p A$-specific oligonucleotide primer of the present study, A. pyogenes 
Table 2. Oligonucleotide primer sequences and PCR conditions used in the present study

\begin{tabular}{|c|c|c|c|c|}
\hline $\begin{array}{l}\text { Oligonucleotide } \\
\text { primer }\end{array}$ & Primer sequence & Program $^{1}$ & $\begin{array}{l}\text { Size of PCR } \\
\text { product (bp) }\end{array}$ & Reference \\
\hline $\operatorname{sodA~Z205^{2}}$ & 5'-AGCTTCACCACAGCAAGCACCA-3' & 1 & 489 & Zolg and Philippi-Schulz (1994) \\
\hline sodA Z212 & 5'-TCGG(T)CCCAGTTCACGACG(A)TTCCA-3' & & & \\
\hline $\operatorname{sod} A 1-\mathrm{F}^{3}$ & 5'-GGCGA(C)T(C)TTTTC(G)CAAGÁTCAACCAG-3' & 2 & 285 & Present study \\
\hline $\operatorname{sod} A 1-\mathrm{R}$ & 5' GTTGGCCTGCTGGTCGAAAAGCTGGAA-3' & & & \\
\hline sodA F (Arcanobacterium pyogenes) & 5'-CGAGCTCGCCGACGCTATTGCT-3' & 3 & 199 & Present study \\
\hline sodA $\mathrm{R}$ (A. pyogenes) & 5'-GAGCATGAGAATCGGGTAAGTGCCA-3' & & & \\
\hline ISR F (A. pyogenes) & 5'-GTTTTGCTTGTGATCGTGGTGGTTATGA-3' & 4 & 122 & Ülbegi-Mohyla et al. (2010b) \\
\hline ISR R (A. pyogenes) & 5'-AAGCAGGCCCACGCGCAGG-3' & & & \\
\hline plo $\mathrm{F}$ & 5'-CGATCCCTCTGGTGTACTTGC-3' & 5 & 704 & Ülbegi-Mohyla et al. (2010b) \\
\hline plo R & 5'-GCTTGACAAAAATCTGGCGTCC-3' & & & \\
\hline $\operatorname{cbp} A \mathrm{~F}$ & 5'-CTTGAAATCGAACTTAAGGCTGG-3' & 6 & 328 & Ülbegi-Mohyla et al. (2010b) \\
\hline $\operatorname{cbp} A \mathrm{R}$ & 5'-ATCGCCAGTCACCTTAGACG-3' & & & \\
\hline nan $H \mathrm{~F}$ & 5'-CGCTAGTGCTGTAGCGTTGTTAAGT-3' & 7 & 781 & Silva et al. (2008) \\
\hline nanH $\mathrm{R}$ & 5'-CCGAGGAGTTTTGACTGACTTTGT-3' & & & \\
\hline $\operatorname{nan} P \mathrm{~F}$ & 5'-TTGAGCGTACGCAGCTCTTC-3' & 7 & 150 & Silva et al. (2008) \\
\hline $\operatorname{nan} P \mathrm{R}$ & 5'-CCACGAAATCGGCCTTATTG-3' & & & \\
\hline $\operatorname{fim} A \mathrm{~F}$ & 5'-CACTACGCTCACCATTCACAAG-3' & 8 & 605 & Silva et al. (2008) \\
\hline $\operatorname{fim} A \mathrm{R}$ & 5'-GCTGTAATCCGCTTTGTCTGTG-3' & & & \\
\hline
\end{tabular}

${ }^{1} \mathrm{PCR}$ program 1: $1 \times\left(95^{\circ} \mathrm{C}, 600 \mathrm{~s}\right), 33 \times\left(94^{\circ} \mathrm{C}, 30 \mathrm{~s}, 39^{\circ} \mathrm{C}, 50 \mathrm{~s}, 72^{\circ} \mathrm{C}, 60 \mathrm{~s}\right), 1 \times\left(72^{\circ} \mathrm{C}, 420 \mathrm{~s}\right) . \mathrm{PCR}$ program $2: 1 \times\left(94^{\circ} \mathrm{C}, 600 \mathrm{~s}\right), 30 \times\left(95^{\circ} \mathrm{C}, 60 \mathrm{~s}, 37^{\circ} \mathrm{C}, 60 \mathrm{~s}, 72^{\circ} \mathrm{C}, 60 \mathrm{~s}\right), 1$ $\times\left(72^{\circ} \mathrm{C}, 420 \mathrm{~s}\right) . \mathrm{PCR}$ program $3: 1 \times\left(94^{\circ} \mathrm{C}, 600 \mathrm{~s}\right), 25 \times\left(94^{\circ} \mathrm{C}, 20 \mathrm{~s}, 62^{\circ} \mathrm{C}, 20 \mathrm{~s}, 72^{\circ} \mathrm{C}, 30 \mathrm{~s}\right), 1 \times\left(72^{\circ} \mathrm{C}, 600 \mathrm{~s}\right) . \mathrm{PCR}$ program $4: 1 \times\left(95^{\circ} \mathrm{C}, 600 \mathrm{~s}\right), 30 \times\left(95^{\circ} \mathrm{C}, 30 \mathrm{~s}, 64^{\circ} \mathrm{C}, 15 \mathrm{~s}\right.$, $\left.72^{\circ} \mathrm{C}, 30 \mathrm{~s}\right), 1 \times\left(72^{\circ} \mathrm{C}, 420 \mathrm{~s}\right) . \mathrm{PCR}$ program $5: 1 \times\left(95^{\circ} \mathrm{C}, 600 \mathrm{~s}\right), 30 \times\left(95^{\circ} \mathrm{C}, 60 \mathrm{~s}, 62^{\circ} \mathrm{C}, 60 \mathrm{~s}, 72^{\circ} \mathrm{C}, 60 \mathrm{~s}\right), 1 \times\left(72^{\circ} \mathrm{C}, 420 \mathrm{~s}\right) . \mathrm{PCR}$ program $6: 1 \times\left(94^{\circ} \mathrm{C}, 600 \mathrm{~s}\right), 30 \times\left(95^{\circ} \mathrm{C}, 30\right.$ s, $\left.58^{\circ} \mathrm{C}, 30 \mathrm{~s}, 72^{\circ} \mathrm{C}, 60 \mathrm{~s}\right), 1 \times\left(72^{\circ} \mathrm{C}, 420 \mathrm{~s}\right) . \mathrm{PCR}$ program $7: 1 \times\left(94^{\circ} \mathrm{C}, 180 \mathrm{~s}\right), 35 \times\left(94^{\circ} \mathrm{C}, 60 \mathrm{~s}, 60^{\circ} \mathrm{C}, 60 \mathrm{~s}, 72^{\circ} \mathrm{C}, 180 \mathrm{~s}\right), 1 \times\left(72^{\circ} \mathrm{C}, 420 \mathrm{~s}\right) . \mathrm{PCR}$ program $8: 1 \times\left(94^{\circ} \mathrm{C}, 180 \mathrm{~s}\right)$, $35 \times\left(94^{\circ} \mathrm{C}, 60 \mathrm{~s}, 57^{\circ} \mathrm{C}, 60 \mathrm{~s}, 72^{\circ} \mathrm{C}, 180 \mathrm{~s}\right), 1 \times\left(72^{\circ} \mathrm{C}, 420 \mathrm{~s}\right)$.

${ }^{2}$ For Arcanobacterium bernardiae DSM $9152^{\mathrm{T}}$, Arcanobacterium hemolyticum DSM $20595^{\mathrm{T}}$, Arcanobacterium phocae DSM $10002^{\mathrm{T}}$, Arcanobacterium pluranimalium DSM $13483^{\mathrm{T}}$, and A. pyogenes DSM $20630^{\mathrm{T}}$

${ }^{3}$ For Arcanobacterium abortisuis DSM 19515 ${ }^{\mathrm{T}}$, Arcanobacterium bonasi DSM $17163^{\mathrm{T}}$, and Arcanobacterium hippocoleae DSM $15539^{\mathrm{T}}$. 


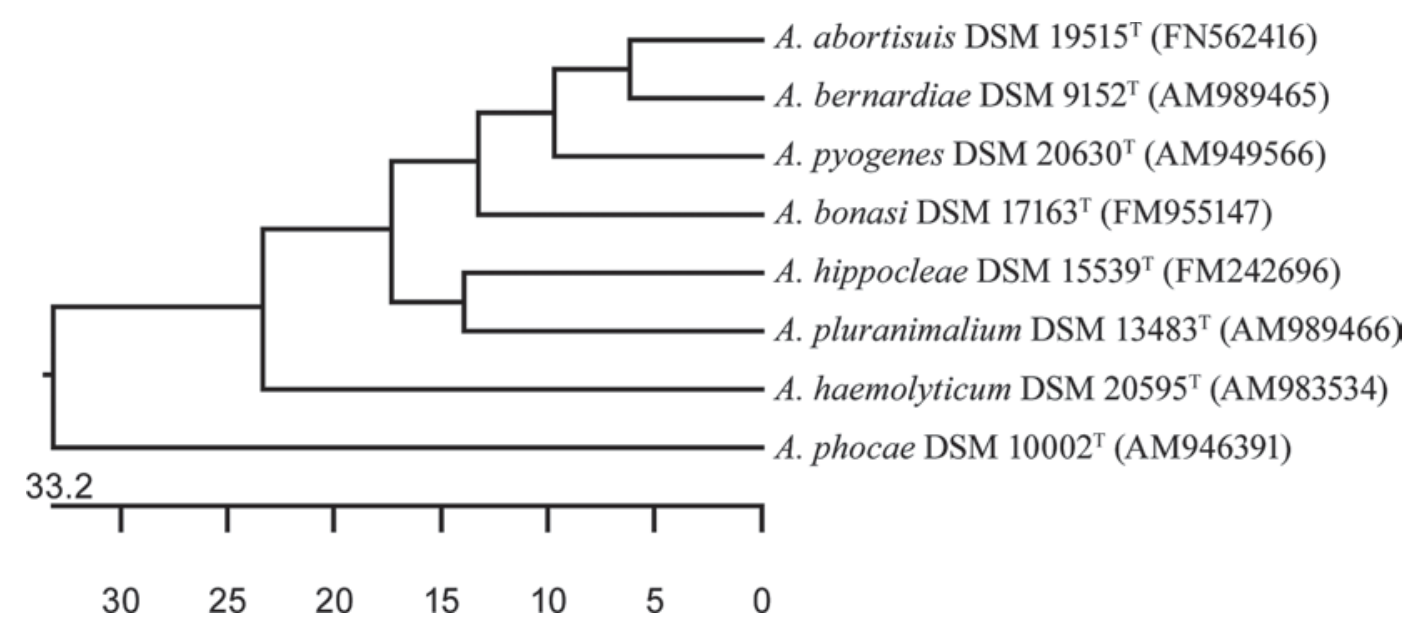
od).

Figure 1. Dendrogram analysis of gene sodA of 8 reference strains of genus Arcanobacterium using the Megalign program (Clustal meth-

DSM 20594 of bovine origin was negative for $\operatorname{cbp} A$. The importance of the distribution of $c b p A$, which occurred more pronounced among $A$. pyogenes isolated from pigs, remains unclear.

According to Jost and Billington (2005), all $A$. pyogenes strains additionally carried nan $\mathrm{H}$ and $64.2 \%$ nanP, which both seem to play a role in the adhesion of this organism to host epithelial cells. In the study of Silva et al. (2008), all investigated A. pyogenes strains carried nanH and nanP. In the present study, 53 (87\%) of the $A$. pyogenes isolates were positive for $n a n H$ and $46(75 \%)$ isolates positive for nanP. However, some of the A. pyogenes isolates of the present study were negative for these putative virulence genes. This negative reaction occurred singly $(\mathrm{n}=8$, negative for nan $H ; \mathrm{n}$ $=11$, negative for $\operatorname{nan} P)$ or in combination $(\mathrm{n}=3$, negative for both nan $H$ and nanP), with no significant differences between the $A$. pyogenes isolates of various origins $(P>0.05)$. However, the nanH-nanP-positive or negative isolates of the present study were not investigated for neuraminidase activity phenotypically.

According to Jost and Billington (2005), fimA encodes a protein with some similarity to the Actinomyces naeslundii type 2 fimbrial subunit and also seems to be involved in adhesion processes. Gene fimA could be found by Jost and Billington (2005), comparable to the findings of the present study, with $98 \%$ fimA-positive isolates, in $94 \%$ of the investigated A. pyogenes isolates. According to Silva et al. (2008), $100 \%$ of the isolates and, according to Santos et al. (2010), $90.9 \%$ of the $A$. pyogenes isolated from metritis compared with $64.1 \%$ of the A. pyogenes isolated from nonmetritic cows, were fimA positive. However, the importance of the differences observed by Santos et al. (2010) remains unclear. In contrast to the findings of Silva et al. (2008) and
Santos et al. (2010), A. pyogenes DSM $20630^{\mathrm{T}}$ (ATCC 19411) investigated in the present study appeared to be fimA negative. The genetic properties of the A. pyogenes isolates of the present study are summarized in Table 2.

The present study gives a detailed genotypic characterization of $A$. pyogenes isolated from bovine mastitis, from nonmastitic origin of bovines, and from several various other animals, indicating that, independent of

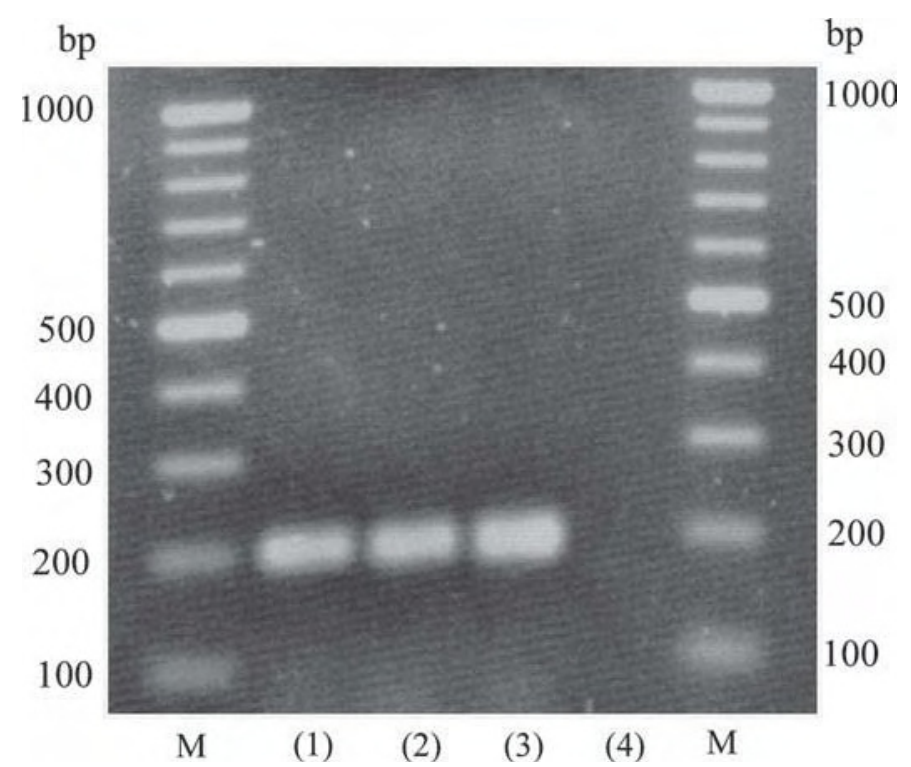

Figure 2. Typical amplicons using the Arcanobacterium pyogenes $\operatorname{sod} A$ gene-specific oligonucleotide primer pair. A. pyogenes DSM $20630^{\mathrm{T}}$ (1) and 2 A. pyogenes isolates of the present study $(2,3)$ with a size of approximately 200 bp. Negative reaction of Arcanobacterium abortisuis DSM $19515^{\mathrm{T}}$ (4). M = GeneRuler 100-bp DNA ladder (Fermentas, St. Leon-Rot, Germany). 
Table 3. PCR-mediated amplification of various known and putative virulence factor encoding genes of Arcanobacterium pyogenes isolated from bovine mastitis and from various other origins

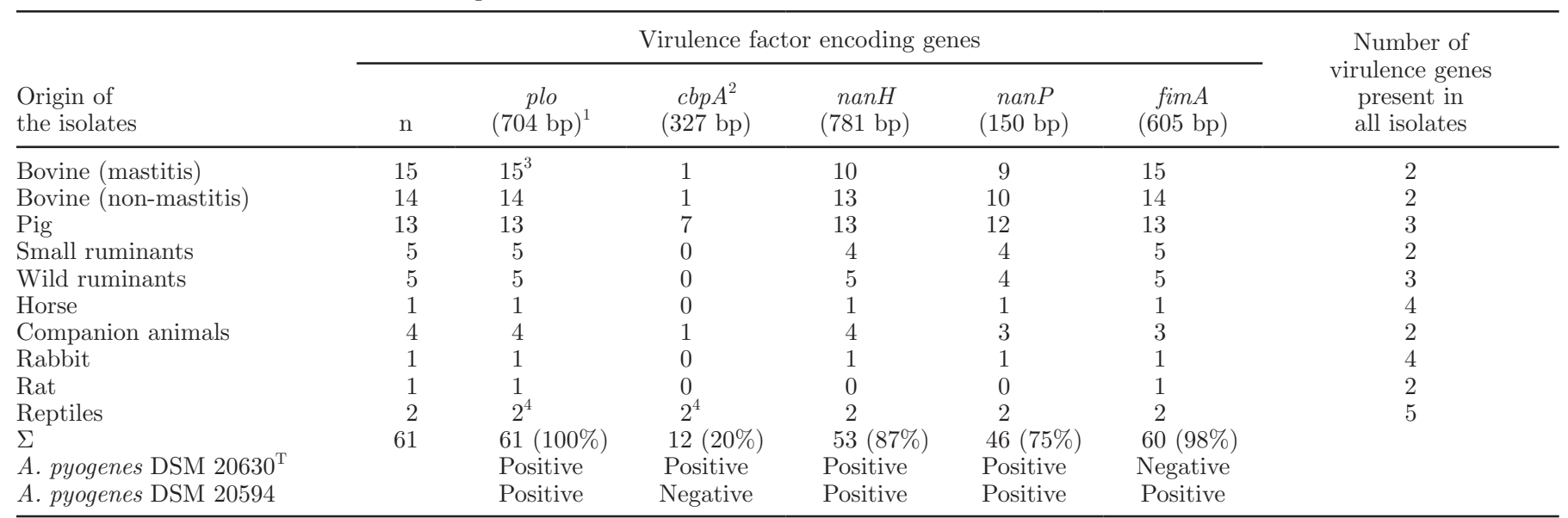

${ }^{1}$ Expected amplicon size.

${ }^{2}$ Significant difference between $A$. pyogenes isolated from ruminants and pigs $(P=0.0004)$.

${ }^{3}$ Number of isolates with the respective property.

${ }^{4}$ Results described previously (Ülbegi-Mohyla et al., 2010b).

the origin of the isolates, the proposed species-specific oligonucleotide primers of the target molecules $\operatorname{sod} A$, ISR, and plo could be used for molecular identification of this species. The additionally investigated potential virulence genes allowed an individual strain characterization and might help to understand the process of infection with this bacterial pathogen.

\section{REFERENCES}

Billington, S. J., B. H. Jost, W. A. Cuevas, K. R. Bright, and J. G. Songer. 1997. The Arcanobacterium (Actinomyces) pyogenes hemolysin, pyolysin, is a novel member of the thiol-activated cytolysin family. J. Bacteriol. 179:6100-6106.

Billington, S. J., K. W. Post, and B. H. Jost. 2002. Isolation of Arcanobacterium (Actinomyces) pyogenes from cases of feline otitis externa and canine cystitis. J. Vet. Diagn. Invest. 14:159-162.

Bisping, W., and G. Amtsberg. 1988. Grampositive, sporenlose Stäbchen. Pages 45-48 in Farbatlas zur Diagnose bakterieller Infektions-erreger der Tiere. W. Bisping and G. Amtsberg, ed. Verlag Paul Parey, Berlin and Hamburg, Germany.

Ding, H., and C. Lämmler. 1992. Evaluation of the API Coryne test system for identification of Actinomyces pyogenes. 39: 273-276.

Ding, H., and C. Lämmler. 1996. Purification and further characterization of a haemolysin of Actinomyces pyogenes. Zentralbl. Veterinarmed. B 43:179-188.

Dixon, W. J. 1993. BMDP Statistical Software Manual, Volume 1 and 2. University of California Press, Berkeley, Los Angeles, London.

Ertaş, H. B., A. Kiliç, G. Özbey, and A. Muz. 2005. Isolation of Arcanobacterium (Actinomyces) pyogenes from abscessed cattle kidney and identification by PCR. Turk. J. Vet. Anim. Sci. 29:455459.

Esmay, P. A., S. J. Billington, M. A. Link, J. G. Songer, and B. H. Jost. 2003. The Arcanobacterium pyogenes collagen-binding protein, CbpA, promotes adhesion to host cells. Infect. Immun. 71:4368-4374.

Hassan, A. A., H. Mohyla, T. Kanbar, J. Alber, C. Lämmler, A. Abdulmawjood, S. Speck, M. Zschöck, and R. Weiss. 2008. Molecular identification of Arcanobacterium bialowiezense and Arcanobacterium bonasi based on $16 \mathrm{~S}-23 \mathrm{~S}$ rRNA intergenic spacer region sequences. Vet. Microbiol. 130:410-414.

Hassan, A. A., H. Ülbegi-Mohyla, T. Kanbar, J. Alber, C. Lämmler, A. Abdulmawjood, M. Zschöck, and R. Weiss. 2009. Phenotypic and genotypic characterization of Arcanobacterium haemolyticum isolates from infections of horses. J. Clin. Microbiol. 47:124-128.

Jost, B. H., and S. J. Billington. 2005. Arcanobacterium pyogenes: Molecular pathogenesis of an animal opportunist. Antonie van Leeuwenhoek 88:87-102.

Jost, B. H., J. G. Songer, and S. J. Billington. 2001. Cloning, expression, and characterization of a neuraminidase gene from $\mathrm{Ar}$ canobacterium pyogenes. Infect. Immun. 69:4430-4437.

Jost, B. H., J. G. Songer, and S. J. Billington. 2002. Identification of a second Arcanobacterium pyogenes neuraminidase and involvement of neuraminidase activity in host cell adhesion. Infect. Immun. 70:1106-1112.

Lämmler, C., and H. Hartwigk. 1995. Actinomyces pyogenes und Arcanobacterium haemolyticum. Pages 196-240 in Handbuch der bakteriellen Infektionen bei Tieren, Band II/3. 2nd ed. H. Blobel and T. Schließer, ed. Gustav Fischer Verlag, Jena, Stuttgart, Germany.

Levy, C. E., R. J. Pedro, A. Von Nowakonski, L. M. Holanda, M. Brocchi, and M. C. Ramo. 2009. Arcanobacterium pyogenes sepsis in farmer, Brazil. Emerg. Infect. Dis. 15:1131-1132.

Moore, R., A. Miyoshi, L. G. C. Pacheco, N. Seyffert, and V. Azevedo. 2010. Corynebacterium and Arcanobacterium. Pages 133-147 in Pathogenesis of Bacterial Infections of Animals. 4th ed. C. L. Gyles, J. F. Prescott, G. Songer, and C. O. Thoen, ed. Iowa State University Press, Ames, IA.

Pietrocola, G., V. Valtulina, S. Rindi, B. H. Jost, and P. Speziale 2007. Functional and structural properties of CbpA, a collagenbinding protein from Arcanobacterium pyogenes. Microbiology 153:3380-3389.

Plamondon, M., G. Martinez, L. Raynal, M. Touchette, and L. Valiquette. 2007. A fatal case of Arcanobacterium pyogenes endocarditis in a man with no identified animal contact: Case report and review of the literature. Eur. J. Clin. Microbiol. Infect. Dis. 26:663-666.

Ramos, C. P., G. Foster, and M. D. Collins. 1997. Phylogenetic analysis of the genus Actinomyces based on 16S rRNA gene sequences: 
Description of Arcanobacterium phocae sp. nov., Arcanobacterium bernardiae comb. nov., and Arcanobacterium pyogenes comb. nov. Int. J. Syst. Bacteriol. 47:46-53.

Santos, T. M. A., L. S. Caixeta, V. S. Machado, A. K. Rauf, R. O. Gilbert, and R. C. Bicalho. 2010. Antimicrobial resistance and presence of virulence factor genes in Arcanobacterium pyogenes isolated from the uterus of postpartum dairy cows. Vet. Microbiol. 145:84-89.

Silva, E., M. Gaivão, S. Leitão, B. H. Jost, C. Carneiro, C. L. Vilela, L. Lopes da Costa, and L. Mateus. 2008. Genomic characterization of Arcanobacterium pyogenes isolates recovered from the uterus of dairy cows with normal puerperium or clinical metritis. Vet. Microbiol. 132:111-118.

Ülbegi-Mohyla, H., A. A. Hassan, J. Alber, C. Lämmler, E. PrengerBerninghoff, R. Weiss, and M. Zschöck. 2010a. Identification of Arcanobacterium pluranimalium isolated from a dog by phenotypic properties and by PCR mediated characterization of various molecular targets. Vet. Microbiol. 142:458-460.

Ülbegi-Mohyla, H., A. A. Hassan, T. Kanbar, J. Alber, C. Lämmler, E. Prenger-Berninghoff, R. Weiss, U. Siebert, and M. Zschöck. 2009.
Synergistic and antagonistic hemolytic activities of bacteria of genus Arcanobacterium and CAMP-like hemolysis of Arcanobacterium phocae and Arcanobacterium haemolyticum with Psychrobacter phenylpyruvicus. Res. Vet. Sci. 87:186-188.

Ülbegi-Mohyla, H., M. Hijazin, J. Alber, C. Lämmler, A. A. Hassan, A. Abdulmawjood, E. Prenger-Berninghoff, R. Weiss, U. Siebert, and M. Zschöck. 2010b. Identification of Arcanobacterium pyogenes isolated by post mortem examination of a bearded dragon and a gecko by phenotypic and genotypic properties. J. Vet. Sci. 11:265-267.

Yassin, A. F., H. Hupfer, C. Siering, and P. Schumann. 2010. Comparative chemotaxonomic and phylogenetic studies on the genus Arcanobacterium Collins et al., 1982 emend. Lehnen et al., 2006: Proposal for Trueperella gen. nov. and emended description of the genus Arcanobacterium. Int. J. Syst. Evol. Microbiol. ijs.0.020032-0.

Zolg, J. W., and S. Philippi-Schulz. 1994. The superoxide dismutase gene, a target for detection and identification of mycobacteria by PCR. J. Clin. Microbiol. 32:2801-2812. 